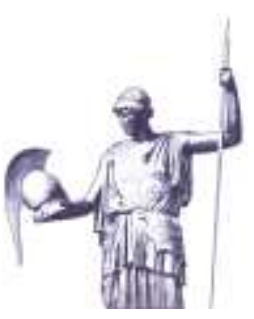

Research Article
Connections: The Quarterly Journal

ISSN 1812-1098, e-ISSN 1812-2973

Flores-Herrera and Penev,

Connections QJ 17, no. 2 (2018): 37-45

https://doi.org/10.11610/Connections.17.2.03

\title{
The Importance of the Council of Europe's 24/7 Network of Contact Points on Foreign Terrorist Fighters
}

\section{Albert Flores-Herrera ${ }^{a}$ and Plamen P. Penev ${ }^{b}$}

a Congress of Local and Regional Authorities, Council of Europe, https://www.coe.int/en/web/congress/home

b Institute for Global History at the University of Vienna, https://www.univie.ac.at/en

\begin{abstract}
The article focusses on the Council of Europe 24/7 Network of Contact Points on Foreign Terrorist Fighters envisaged in article 7 of the Additional Protocol to the Council of Europe Convention on the Prevention of Terrorism adopted on 22 October 2015. The Protocol supplements the 2005 Council of Europe Convention on the Prevention of Terrorism and it entered into force on July 1, 2017. The Protocol addresses the imminent security threat originating from "foreign terrorist fighters" (FTFs) who are returning to their countries of origin or are trying to relocate in third countries as a result of Daesh's military defeat and collapse. Those 'returnees,' i.e, FTFs and their families, pose a tremendous challenge with no easy solution for law-enforcement agencies and societies across Europe, and combatting the menace requires full compliance with international law.
\end{abstract}

Keywords: Additional Protocol, Convention on the Prevention of Terrorism, exchange of information, foreign terrorist fighters, Council of Europe, UN Resolution 2178, 24/7 Network, Europol, European Counter Terrorism Center. 


\section{Additional Protocol to the Council of Europe Convention on Preven- tion of Terrorism}

This article focusses on the Council of Europe 24/7 Network of Contact Points on Foreign Terrorist Fighters (hereinafter "the Network") envisaged in article 7 of the Additional Protocol to the Council of Europe Convention on the Prevention of Terrorism ${ }^{1}$ (hereinafter "the Protocol") which was adopted on 22 October 2015 in Riga, Latvia. The Protocol supplements the 2005 Council of Europe Convention on the Prevention of Terrorism (hereafter "the 2005 Convention") and it entered into force on 1 July 2017. The Protocol addresses the imminent security threat originating from "foreign terrorist fighters" (hereinafter "FTFs") who are returning to their countries of origin or are trying to relocate in third countries as a result of Daesh's collapse (military defeat). Those 'returnees' -FTFs and their families-pose a tremendous challenge with no easy solution for law-enforcement agencies and societies across Europe, and combatting the menace requires full compliance with international law.

The Protocol follows thereby the UNSC Resolution 2178 (2014) that has set legal obligations with regard to the criminalization of preparatory acts of terrorism, the commission of terror attacks and the provision of or receiving terrorist training. ${ }^{2}$ As a result of the adoption of the UNSR Resolution 2178 (2014), the Council of Europe's Committee of Experts on Terrorism (CODEXTER-CDCT) called out for the creation of a committee which was tasked with the creation of the Additional Protocol to the 2005 Convention on the Prevention of Terrorism (Treaty No.196). The final drafting was completed in 2015 after comprehensive deliberations and consultations with the Parliamentary Assembly of the Council of Europe.

The Additional Protocol criminalizes the following acts:

- Participating in the activities of an association or group for the purpose of committing or contributing to the commission of one or more terrorist offences (Article 2);

- Receiving training for terrorism (including obtaining knowledge or practical skills) in the making or use of explosives, firearms, weapons or hazardous substance, or in other specific methods or techniques, for the purpose of terrorism (Article 3);

- Travelling to a country other than the traveler's residence or nationality for the purpose of the commission of, contribution to or participation in

1 "Additional Protocol to the Council of Europe Convention on the Prevention of Terrorism," Council of Europe Treaty Series no. 217, adopted in Riga, October 22, 2015, accessed June 18, 2018, https://www.coe.int/en/web/conventions/full-list//conventions/rms/090000168047c5ea.

2 "Threats to International Peace and Security Caused by Terrorist Acts," S/RES/2178 (2014), UN Security Council, September 24, 2014, http://unscr.com/files/2014/021 78.pdf. 
a terrorist offence, or the providing or receiving of training for terrorism (Article 4);

- Providing (in)direct financial support or collecting funds fully or partially enabling any person to travel abroad for the purpose of terrorism (Article 5);

- $\quad$ Organizing or otherwise assisting any person in travelling abroad for the purpose of terrorism (Article 6).

\section{Foreign Terrorist Fighters (FTFs)}

There is a variety of definitions referring to the term "Foreign Terrorist Fighter," but it is generally accepted that the term applies to non-indigenous individuals who have chosen to leave their countries of origin and to engage in insurgent (military) combat activities in foreign conflict areas without the promise of financial reward. ${ }^{3}$ Correspondingly, the Islamic FTFs have been defined as (un)paid combatants with no apparent connection to the conflict zone other than religious attraction. ${ }^{4}$ Equally important is the fact that the number of FTFs involved in a given war-torn region, together with the capabilities and know-how they imbue the local insurgency with, can play a significant and even decisive role in a conflict zone (examples of this are the Mujahedeen ganging up with the Taliban during the Afghanistan conflict in the 1980s, or the FTFs in the Bosnian and Chechen conflicts in the 1990s). According to data provided by the UN Under-Secretary-General of the newly created UN Counter-Terrorism Office, Mr. Vladimir Voronkov, there are at least 5,600 FTFs originating from 33 countries who have already returned home. ${ }^{5}$ Many of them have fallen off the radar of law-enforcement agencies and since they have been well-trained and equipped during the time they have spent in Daesh-controlled territories, many of them have the capability to wreak havoc with terrorist attacks in their home countries. Further radicalization and the readiness to recruit followers to serve the Daesh's cause are two aspects that should not be overlooked.

Although Daesh has been defeated, its ideology still lives on and might be exported worldwide via returning FTFs. Thus, the Council of Europe and UN

3 For a detailed discussion concerning the academic term "foreign terrorist fighter," refer to Sandra Kraehenmann, "Foreign Terrorist Fighters under International Law," Academy Briefing no. 7 (Geneva: Geneva Academy of International Humanitarian Law and Human Rights, October 2014), 5-7, https://www.geneva-academy.ch/joomlatoolsfiles/docman-files/Publications/Academy\%20Briefings/Foreign\%20Fighters_2015_ WEB.pdf.

4 Thomas Hegghammer, "The Rise of Muslim Foreign Fighters: Islam and Globalization of Jihad," International Security 35, no. 2 (Winter 2010-2011), 53.

5 See also Richard Barrett, Beyond the Caliphate: Foreign Fighters and the Threat of Returnees (New York: The Soufan Center and the Global Strategy Network, October 2017), accessed June 19, 2018, http://thesoufancenter.org/research/beyondcaliphate. 
member states are required to strengthen their cooperation and exchange of information, developing effective security checks on the borders, and synchronizing and upgrading their criminal justice system in compliance with the rule of law and human rights standards. Keeping in mind that the threat that FTFs pose still stands, ${ }^{6}$ and in order to facilitate the exchange of information, it is of crucial importance for the European security that all Council of Europe member states and the $\mathrm{EU}^{7}$ implement Article 7 of the Protocol, ${ }^{8}$ which calls for the creation of a network of nationally designated focal points giving the 47 member states the opportunity to exchange police information "concerning persons travelling abroad for the purpose of terrorism," that is: related to persons suspected of plotting, supporting or committing a terrorist attack, or providing or receiving training for terrorism. Article 7 stipulates explicitly the exchange of police information in a timely and expedited manner and requires member states to appoint official points of contact who will communicate fast and exchange police information on FTF with their counterparts.

However, legal experts dealing with the Council of Europe 24/7 Network of Contact Points on FTFs expressed concerns over its functioning and referred to the deficits a prospective cooperation among the parties to the Protocol might reveal. As an example of miscommunication and tardy exchange of police information, it is worth noting here the case of the Berlin truck attacker Mr. Anis Amri, who killed 12 people and injured more than 60 in a Berlin Christmas market

6 After losing almost all the ground made, Daesh's strategy for 2018 seems to point towards a regrouping of its members in Syria and Iraq, while maintaining its threat through low-level mass-casualty attacks and continuing to exhort its supporters to launch attacks in their home countries. For further information, see Matthew Henman, "Global Militant Attacks Caused Fewer Fatalities in 2017," IHS Markit, January 18, 2018, https://ihsmarkit.com/research-analysis/global-militant-attacks-causedfewer-fatalities-in-2017.html.

7 The EU ratified the Protocol on 22 October 2015 and in a statement prior to the ratification Commissioner D. Avramopolus (Migration, Home Affairs and Citizenship) commented on the text by highlighting the importance of the Protocol: "Today is an important step ahead in combatting a global security challenge with concrete, legal tools. Fighting terrorism is a top priority for the coming years, and today's signing will be instrumental to giving the European Union the right toolbox to do so."

8 Article 7 (Exchange of information) of the Protocol states:

1. Without prejudice to Article 3, paragraph 2, sub-paragraph a, of the Convention [on the Prevention of Terrorism] and in accordance with its domestic law and existing international obligations, each Party shall take such measures as may be necessary in order to strengthen the timely exchange between Parties of any available relevant information concerning persons travelling abroad for the purpose of terrorism, as defined in Article 4. For that purpose, each Party shall designate a point of contact available on a 24-hour, seven-days-a-week basis.

2. A Party may choose to designate an already existing point of contact under paragraph 1.

3. A Party's point of contact shall have the capacity to carry out communications with the point of contact of another Party on an expedited basis. 
on 19 December 2016, ${ }^{9}$ the investigation of which revealed a plethora of failures on the part of the German authorities and evinced a poor cooperation and exchange of relevant data concerning the suspect between police forces in Germany. ${ }^{10}$

Given these points and in order to mitigate the consequences of potential future blunders - the CODEXTER-CDCT has tested the efficiency of the Network with the aim to verify how the nationally nominated points of contact interact with each other and to what extent valuable information on FTF is shared and properly communicated. On closer consideration, the CODEXTER-CDCT aims to improve the exchange of FTF-related data by bridging over the distrust which has been prevalent over the last years among law-enforcement agencies and within the intelligence communities and that has hindered the rapid exchange of reliable information.

\section{State of Play}

On 18 May 2016, at a Ministerial Session in the Bulgarian capital of Sofia, the Committee of Ministers of the Council of Europe "called for the expeditious designation of the $24 / 7$ contact points to facilitate the timely exchange of information, as provided for by the Additional Protocol to the Council of Europe Convention on the Prevention of Terrorism (CETS No. 217), pending its entry into force." ${ }^{11}$ The newly installed Network started its operational work on December 1, 2016 and encompasses 41 designated contact points, including one for the EU. The CODEXTER-CDCT held the first meeting of the nominated points of contact on October 17, 2016 at its headquarters in Strasbourg, offering the participants the possibility to further discuss key subjects concerning the Network such as its potential added value, technicalities related to securing a rapid and flawless exchange of information, protection of information sources, and confidentiality of the offered information. As a result of the first meeting, the CODEXTER-CDCT and the participating parties to the Protocol agreed on the crucial significance of the Network as a reliable information hub which enables the points of contact "to request, send and receive information vis-à-vis other Contact Points, and to

9 "Berlin Christmas market attack: Inquiry accuses police of 'sloppiness' in Anis Amri case," Deutsche Welle, October 12, 2017, http://www.dw.com/en/berlin-christmasmarket-attack-inquiry-accuses-police-of-sloppiness-in-anis-amri-case/a-40924403.

10 As per the report written by Mr. Bruno Jost, a former German prosecutor appointed by Berlin's state parliamentary inquiry into the Berlin Christmas market attacker (a former German prosecutor appointed by Berlin's state parliamentary inquiry) see "Abschlussbericht des Sonderbeauftragten des Senats für die Aufklärung des Handelns der Berliner Behörden im Fall AMRI," https://www.berlin.de/sen/inneres/ presse/weitere-informationen/artikel.638875.php.

11 List of Decisions of the Committee of Ministers of the Council of Europe on "Tackling violent extremism and radicalisation leading to terrorism," $126^{\text {th }}$ Session of the Committee of Ministers of the Council of Europe, Sofia, Bulgaria, May 18, 2016, https://rm.coe.int/1680650870. 
channel such requests or information to other relevant national-level authorities without delay." 12

A second meeting of the designated contact points took place on 21 March 2017 in Strasbourg, where CODEXTER-CDCT pundits along with national representatives of the Network's points of contact reviewed the Network's efficiency and accuracy based on gathered data and experience. Additionally, the meeting aimed at expunging shortcomings in the operative readiness of the contact points, improving the efficacy of the established communication channels, verifying the exactitude of the most frequently applied data, and validating the speediness of the Network. Extensive discussions on how to further improve the Network and how to identify and overcome unforeseen or unanticipated mishaps, along with detailed proposals and objectives for improvement, were debated in great detail. Furthermore, the Secretariat of the CODEXTER-CDCT briefed the designated points of contact on the final outcome of a 'ping test' carried out to examine and assess the Network's operative and functional status.

\section{The 'Ping Test'}

The 'Ping Test' consisted of sending out an e-mail to all contact points and requesting them to swiftly acknowledge receipt. In this light, the parties to the Protocol and the CODEXTER-CDCT concurred with the need to conduct more 'ping tests' in the future in order to assess the efficiency and promptness of the Network. In the framework of the 'ping test,' it has been vividly demonstrated that it is hugely important for all the participants to be easily reachable on a 24/7 basis when exchanging information via the Network. The participating states took note of the recommendations and conclusions extracted from the 'ping test' and agreed on enhancing the cooperation between the designated contact points themselves, on one hand, and between the Secretariat of the Council of Europe and the national contact points on the other. ${ }^{13}$

There is a third meeting of the designated contact points scheduled April 2018 where representatives of national contact points will share experiences and information with their counterparts and the Secretariat of the Council of Europe about how the Network is being run in the different countries and how the Network operates in the realm of national legislation. National contact points will be given the opportunity to share examples of best practice with their counterparts as well as to elaborate on strategies aiming to increase mutual trust when sharing sensitive information related to FTFs. In addition, feedback on the

12 CODEXTER, "24/7 Network of Contact Points on Foreign Terrorist Fighters Information provided by the Secretariat," CODEXTER (2017) 3, Strasbourg, France, May 4, 2017, https://rm.coe.int/168070f25a.

13 CODEXTER, "24/7 Network of Contact Points on Foreign Terrorist Fighters Information provided by the Secretariat - Update," CODEXTER (2017) 3rev, Strasbourg, France, November 3, 2017, https://rm.coe.int/updated-informationdocument-on-24-7-ftf-network/1680764662. 
efficiency of the Network will further contribute to the improvement of the established communication channels (e-mail, phone).

\section{7 is more than $28(-1)$}

Given the constituency of the Council of Europe, a European international organization consisting of 47-member states-compared to the EU-28 minus 1-it is recommended for the participating states to take measures to:

- $\quad$ Exchange information on Foreign Terrorist Fighters by using the 24/7 Network in a reliable and rapid manner as timely shared information is key to identify FTFs and prevent them from crossing borders;

- $\quad$ Note that the Council of Europe consists of 47-member states, among others Turkey, Albania, FYROM, Russia, Azerbaijan, Montenegro, Bosnia and Herzegovina, countries from which many FTFs teamed up with Daesh in the period 2014-2017 and whose returnees have already moved back to their home countries; ${ }^{14}$

- Further rely on existing tools for the exchange of information and intelligence on FTFs and ensure their interoperability, such as Europol's Focal Point Travelers database, Europol's Secure Information Exchange Network Application (SIENA) and the European Information System (EIS), the second-generation Schengen Information System (SIS II), Prüm Connections, and the Interpol's Counter-terrorism Fusion Center and the I24/7 Global Police Communication System;

- Share the Network's data with the Europol's European Counter Terrorism Center (ECTC) to identify and tackle FTFs, because international cooperation among counter terrorism authorities is crucial;

- Carry out 'ping tests' regularly and share the results with the contact points for further evaluation, thus making room for suggestions and ideas on how to constantly improve the Network's performance;

- Encourage the member states of the Council of Europe to increase the flow of information within the Network, to promptly respond to inquiries made by requesting states when information on FTFs is needed, and to optimize the information with partner states, keeping in mind that returning FTFs after Daesh's collapse will opt to either find new safe havens, e.g. in Libya, or return to their countries of origin and pose an imminent threat to internal security of the states concerned;

14 For more precise information related to data and exact numbers, refer to the reports published by the Soufan Center: Richard Barrett, Beyond the Caliphate: Foreign Fighters and the Threat of Returnees; Foreign Fighters: An Updated Assessment of the Flow of Foreign Fighters into Syria and Iraq (December 2015); and Richard Barrett, Foreign Fighters in Syria (June 2014). 
- Promote the Council of Europe 24/7 Network of Contact Points on Foreign Terrorist Fighters as an efficient tool to combat FTFs and more effectively trace emerging trends and routes;

- Publish case studies related to the successful exchange of information on FTFs in real time demonstrating the functioning of the Network and highlighting the fact that a rapid and accurate communication among the involved participants can be deemed essential to target potential FTFs and prevent them from travelling across European borders for the purpose of terrorism;

- Ward off a potential misuse of the Network by some member states for solving domestic political problems, such as including innocent persons on the FTF list and designating them as FTFs only because they are regarded as regime opponents. It is worth mentioning here that the parties to the Protocol must respect human rights standards and obligations, including the European Convention on Human Rights and the International Covenant on Civil and Political Rights, especially when it comes to the criminalization of preparatory terrorist acts (as set forth in Article 8 of the Protocol). ${ }^{15}$

- Sign and ratify the Protocol, since to date it has been ratified by 10 member states of the Council of Europe, and another 28 member states and the EU have signed but not yet ratified the Protocol;

- Reinforce the cooperation among international bodies dealing with terrorism, such as the UN Counter-Terrorism Committee Executive Directorate (CTED), the United Nations Office on Drugs and Crime (UNODC), the Organization for Security and Cooperation in Europe (OSCE), the Europol's European Counter Terrorism Center (ECTC), the Global CounterTerrorism Forum (GCTF), and the NATO Center of Excellence on Defense against Terrorism in Ankara (Albania will soon host a NATO Center of Excellence on Foreign Fighters).

15 For additional information on conditions and safeguards of the Protocol, refer to its Explanatory Report, paragraphs 69-79, https://rm.coe.int/168047c5ec. 


\section{About the Authors}

Albert FLORES-HERRERA works at the Congress of Local and Regional Authorities of the Council of Europe, especially on preventing corruption and fostering transparency at local and regional levels. Previously, he held other positions within the Council of Europe in the fields of criminal law and counter-terrorism. His professional background includes experiences in Europol, the European Commission and the United Nations Office on Drugs and Crime.

Plamen P. PENEV is current visiting fellow at the Institute for Global History at the University of Vienna. He graduated from the University in Vienna majoring in Sociology with minors in Political Science and Mass Communication. In 2011 he finished his PhD project at the Institute for International Affairs, University of Vienna. He was visiting research fellow at the UN CTBTO, EU Commission DG RTD, EUI Florence, Council of Europe - CODEXTER, Eurojust and the Institute for International Relations in Prague. His main research interests lie in the fields of Disarmament, Arms Control, Nuclear/WMD Non-Proliferation, CTBT, NPT, Nuclear-Weapon-Free Zones (NWFZ)-UNODA.

E-mail: penplam@outlook.com. 


\section{Bibliography}

"Abschlussbericht des Sonderbeauftragten des Senats für die Aufklärung des Handelns der Berliner Behörden im Fall AMRI," Berlin.de, 2018, https://www.berlin.de/sen/inneres/presse/weitere-informationen/artikel. 638875.php.

"Additional Protocol to the Council of Europe Convention on the Prevention of Terrorism," Council of Europe Treaty Series no. 217, adopted in Riga, October 22, 2015, 2018, https://www.coe.int/en/web/conventions/full-list//conventions/rms/090000168047c5ea.

"Berlin Christmas Market Attack: Inquiry Accuses Police of 'Sloppiness' in Anis Amri Case," Deutsche Welle, October 12, 2017, www.dw.com/en/berlinchristmas-market-attack-inquiry-accuses-police-of-sloppiness-in-anis-amricase/a-40924403.

"Tackling Violent Extremism and Radicalisation Leading to Terrorism," 26th Session of the Committee of Ministers of the Council of Europe, Sofia, Bulgaria, May 18, 2016, https://rm.coe.int/1680650870.

"Threats to International Peace and Security Caused by Terrorist Acts," UN Security Council, S/RES/2178, September 24, 2014, http://unscr.com/files/ 2014/02178.pdf.

Barrett, Richard, Beyond the Caliphate: Foreign Fighters and the Threat of Returnees. New York: The Soufan Center and the Global Strategy Network, October 2017, http://thesoufancenter.org/research/beyond-caliphate.

Barrett, Richard, Beyond the Caliphate: Foreign Fighters and the Threat of Returnees; Foreign Fighters: An Updated Assessment of the Flow of Foreign Fighters into Syria and Iraq. New York: The Soufan Center, December 2015.

Barrett, Richard, Foreign Fighters in Syria. New York: The Soufan Center, June 2014, http://soufangroup.com/wp-content/uploads/2014/06/TSG-ForeignFighters-in-Syria.pdf.

CODEXTER, "24/7 Network of Contact Points on Foreign Terrorist Fighters Information provided by the Secretariat," Strasbourg, France, May 4, 2017, https://rm.coe.int/168070f25a.

CODEXTER, "24/7 Network of Contact Points on Foreign Terrorist Fighters Information provided by the Secretariat - Update," Strasbourg, France, November 3, 2017, https://rm.coe.int/updated-information-document-on24-7-ftf-network/1680764662.

Hegghammer, Thomas, "The Rise of Muslim Foreign Fighters: Islam and Globalization of Jihad," International Security 35, no. 3 (2011): 53-94.

Henman, Matthew, "Global Militant Attacks Caused Fewer Fatalities in 2017," IHS Markit, January 18, 2018, https://ihsmarkit.com/research-analysis/ global-militant-attacks-caused-fewer-fatalities-in-2017.html. 
Kraehenmann, Sandra, "Foreign Terrorist Fighters under International Law," Academy Briefing no. 7 (Geneva: Geneva Academy of International Humanitarian Law and Human Rights, October 2014): 5-7, https://www.genevaacademy.ch/joomlatools-files/docman-files/Publications/Academy\%20 Briefings/Foreign\%20Fighters_2015_WEB.pdf. 